\title{
PERBEDAAN PEMBERIAN KOMPRES AIR HANGAT DENGAN KOMPRES JAHE TERHADAP PENURUNAN NYERI REMATIK PADA LANSIA: STUDI KASUS
}

\author{
Devi Ratna Putri', Ratna Kusuma Astuti ${ }^{2}$ \\ 1.2Akademi Keperawatan Insan Husada Surakarta \\ email:nana_100389@yahoo.co.id
}

\begin{abstract}
Abstrak
Pendahuluan: Rematik merupakan salah satu penyakit tidak menular yang sering terjadi pada lansia. Rematik menyerang anggota tubuh yang bergerak, yaitu bagian tubuh yang berhubungan antara yang satu dengan yang lain dengan perantaraan persendian.

Tujuan: Tujuan penelitian untuk mengetahui perbedaan pemberian kompres air hangat dengan kompres jahe terhadap penurunan nyeri rematik pada lansia di Desa Blulukan, Colomadu, Karanganyar.

Metode: Penelitian ini menggunakan metode studi kasus yaitu rancangan penelitian mencakup pengkajian satu unit penelitian secara intensif membahas suatu pasien dan keluarga. Penelitian dilakukan di Desa Blulukan, Colomadu, Karanganyar. Subjek penelitian 2 responden lansia yang memenuhi kriteria inklusi.

Hasil: Hasil penelitian menunjukkan bahwa nyeri sebelum dilakukan kompres air hangat dengan kompres jahe adalah skala 6 dan nyeri sesudah dilakukan kompres air hangat menjadi skala 4 sedangkan nyeri sesudah dilakukan kompres jahe menjadi skala 3.

Kesimpulan: Kesimpulan kompres jahe lebih efektif dibandingkan kompres air hangat dalam penurunan nyeri rematik pada lansia.
\end{abstract}

Kata Kunci: rematik, kompres air hangat, kompres jahe, nyeri

\section{Abstract}

Background: Rheumatism is one of the non-communicable diseases that often occurs in the elderly. Rheumatism attacks moving limbs, namely body partsthat are related to one another by mediating joints.

Purpose: The purpose to determine the differences in the administration of warm water compresses with ginger compresses to reduce rheumatic pain in the elderly in Blulukan Village, Colomadu, Karanganyar.

Method: This research uses a case study method, which is a research design that includes an intensive study unit study discussing a patient and family. The research was conducted in Blulukan Village, Colomadu, Karanganyar. Research subjects 2 elderly respondents who met the inclusion criteria.

Result: The results showed that pain before compressing warm water with a ginger compress was a scale of 6 and pain after compressing warm water into a scale 4 while after ginger compresses became a scale 3.

Conclusion: The ginger compresses were more effective than warm water compresses in reducing rheumatic pain in the elderly.

Keywords: rheumatism, warm water compresses, ginger compresses, pain 


\section{Pendahuluan}

Lanjut usia adalah mereka yang telah mencapai usia lebih dari 60 tahun. Indonesia termasuk dalam lima besar Negara dengan jumlah lansia terbanyak di dunia. Pada tahun 2018, jumlah penduduk lanjut usia di Indonesia menjadi 24,7 juta jiwa dan diperkirakan pada tahun 2025 jumlahnya akan mencapai 36 juta jiwa (Kemenkes RI, 2015).Lanjut usia pada umunya banyak mengalami penurunan fisiologis akibat proses alamiah yaitu proses menua (aging) sehingga penyakit tidak menular banyak terjadi pada lanjut usia. Diantaranya hipertensi, rematik, stroke dan diabetes melitus (Direktorat Statistik Kesejahteraan Rakyat, 2015).

Rematik merupakan salah satu penyakit tidak menular yang sering terjadi pada lansia (Nugroho, 2010). Rematik menyerang anggota tubuh yang bergerak, yaitu bagian tubuh yang berhubungan antara yang satu dengan yang lain dengan perantaraan persendian.Semua jenis rematik menimbulkan rasa nyeri yang mengganggu, penyakit yang kronis dapat mengakibatkan gangguan gerak, hambatan dalam bekerja maupun melaksanakan kegiatan sehari-hari, sehingga dapat menimbulkan frustasi atau gangguan psikososial penderita dan keluarganya (Basudewa, 2009).

Gejala yang sering munculpada penyakit rematik adalah nyeri. Martono (2009) menyatakan bahwa keluhan nyeri yang timbul dapat menganggu penderita, sehingga penderita tidak dapat beraktifitas dengan nyaman. Oleh karena itu, penanganan yang pertama kali harus kita lakukan adalah mengurangi nyeri atau gejala yang ditimbulkan.

Tindakan kompres yang dilakukan sesuai dengan aturan dapat menurunkan tingkat nyeri pada lansia yang mengalami nyeri rematik. Kompres dapat meningkatkan suhu jaringan dan sirkulasi darah lokal, yang dapat menghambat produk metabolisme inflamasi seperti prostaglandin, bradykinin dan histamine sehingga dapat mengurangi nyeri. Selain itu, perubahan fisik pada jaringan kolagen, peningkatan aktivitas metabolisme, penurunan kram otot, perubahan respon neurologis, kegiatan sistem muskuloskeletal, kekutan dan daya tahan otot, perasaan panas dan hangat dapat meningkatkan kenyamanan dan mengurangi kecemasan. Hasil penelitian Lestari (2014), menunjukkan bahwa terapi kompres jahe pada penderita rematik dapat mengurangi nyeri karena jahe dapat menstimulasi kulit dan memberikan efek relaksasi. Jahe mengandung senyawa Phenol yang terbukti memiliki efek anti radang dan diketahui ampuh mengusir penyakit sendi juga ketegangan yang dialami otot sehingga dapat memperbaiki sistem muskuloskeletal yang menurun. 


\section{Tujuan}

Penelitian ini bertujuan untuk mengetahui perbedaan pemberian kompres air hangat dengan kompres jahe terhadap penurunan nyeri rematik pada lansia di Desa Blulukan, Colomadu, Karanganyar.

\section{Metode}

Penelitian ini menggunakan metode studi kasus adapun subyek dalam penelitian ini adalah 2 lansia dengan nyeri rematik di Desa Blulukan, Colomadu, Karanganyar dengan membandingkan kelompok intervensi (kompres jahe) dan kelompok kontrol (kompres air hangat). Instrumen yang digunakan adalah lembar Visual Analog Scale (VAS). VAS adalah alat pengukuran intensitas nyeri efisien yang telah digunakan secara luas dalam penelitian dan pengaturan klinis.

\section{Hasil}

Hasil yang didapatkan dari penelitian ini adalah sebagai berikut:

1. Karakteristik Responden Berdasarkan Usia

Distribusi frekuensi responden berdasarkan usia di Desa Blulukan, Colomadu, Karanganyar didapatkan hasil dari 2 orang responden, pada responden kompres air hangat berusia 65 tahun dan pada responden kompres jahe berusia 66 tahun.

2. Karakteristik Responden Berdasarkan Jenis Kelamin

Distribusi frekuensi responden berdasarkan jenis kelamin di Desa Blulukan, Colomadu, Karanganyar didapatkan hasil kedua responden dari responden kompres air hangat dengan kompres jahe sama-sama berjenis kelamin perempuan.

3. Karakteristik Responden Berdasarkan Pekerjaan

Distribusi frekuensi responden berdasarkan pekerjaan di Desa Blulukan, Colomadu, Karanganyar didapatkan hasil kedua responden dari kelompok kompres air hangat dan kompres jahe sama-sama bekerja sebagai ibu rumah tangga.

4. Perbandingan Skala Nyeri Rematik Sebelum dan Sesudah Diberi Kompres

Distribusi frekuensi responden berdasarkan skala nyeri rematik sebelum dan sesudah diberi kompres di Desa Blulukan, Colomadu, Karanganyar yang akan dijelaskan pada tabel dibawah ini:

Tabel 1 Skala Nyeri Sebelum dan Sesudah Diberi Kompres

\begin{tabular}{lcc}
\hline \multicolumn{1}{c}{ Responden } & Sebelum & Sesudah \\
\hline Kompres Air Hangat & 6 & 4 \\
Kompres Jahe & 6 & 3 \\
\hline
\end{tabular}

Berdasarkan tabel 1 diketahui bahwa perbandingan skala nyeri sebelum diberi kompres air hangat dengan kompres jahe adalah sama yaitu skala 6. Perbandingan 
skala nyeri sesudah diberi kompres air hangat adalah 4 sedangkan skala nyeri sesudah diberi kompres jahe adalah 3 .

\section{Pembahasan}

Pada penelitian ini karakteristik usia responden berada pada rentan 65-66 tahun. Menurut Nugroho (2010) hampir 8\% orang yang berusia 60 tahun keatas mempunyai keluhan pada sendinya, terutama linu, pegal, dan kadang-kadang terasa sangat nyeri. Lansia sering mengalami nyeri pada persendian, yang disebabkan karena proses degeneratif dari sel-sel sehingga sangat menganggu aktivitas sehari-hari.

Nyeri sendi cenderung lebih banyak diderita oleh perempuan dengan perbandingan tiga kali lebih sering dibanding laki-laki. Penelitian dari Wulan (2015), juga mengatakan bahwa nyeri sendi terjadi pada usia lanjut dan sering muncul ketika perempuan telah memasuki masa menopause. Ada beberapa faktor yang mempengaruhi nyeri antara lain usia, kelemahan, fungsi neurologis, perhatian, pengalaman sebelumnya, faktor spiritual, kecemasan, teknik koping dan arti dari nyeri (Potter \& Perry, 2009).

\section{Penurunan Skala Nyeri Rematik Sebelum dan Sesudah diberi Kompres Air Hangat}

\section{dengan Kompres Jahe}

Berdasarkan Tabel 1 menunjukkan skala nyeri rematik sebelum diberi terapi kompres air hangat pada lansia didapatkan nilai skala 6 dan skala nyeri sebelum diberi terapi kompres jahe didapatkan nilai skala 6. Skala nyeri sesudah diberi terapi kompres air hangat selama 7 (tujuh) hari didapatkan nilai skala 4 sedangkan skala nyeri sesudah diberi terapi kompres jahe selama tujuh hari didapatkan nilai skala 3. Data yang telah didapatkan tersebut memiliki makna terdapat perbedaan pemberian kompres air hangat dengan kompres jahe terhadap penurunan nyeri rematik pada lansia.

Hasil yang didapatkan dapat diperkuat dengan hasil penelitian yang telah dilakukan oleh Rusnoto, dkk (2015) bahwa dengan pemberian kompres jahe dapat meringankan skala nyeri pada pasien asam urat di Desa Kedungwungu, Tegowanu,Grobogan.

Kompres hangat juga dapat menurunkan nyeri dengan cara menggunakan metode stimulus kutaneus. Menurut Yohana (2017), mengatakan bahwa kompres hangat dapat memberikan dampak yang efektif untuk lansia yang merasakan nyeri, dimana pada saat kompres diletakkan ditempat yang nyeri maka rasa panas tersebut akan berpindah ketubuh atau kulit, sehingga terjadilah proses konduksi yang terjadi pada tubuh sehingga menyebabkan vasodilatasi pembuluh darah dan menurunkan otot yang tegang agar otot menjadi relaksasi dan rasa nyeri akan berkurang. 


\section{Perbedaan Pemberian Kompres Air Hangat dengan Kompres Jahe Terhadap Penurunan Nyeri Rematik Pada Lansia}

Tabel 1 menunjukkan hasil skala penurunan nyeri pada kelompok kompres jahe dengan nilai skala 3, sedangkan kelompok kompres air hangat dengan nilai skala 4. Hasil skala penurunan nyeri dengan kompres jahe lebih tinggi dalam menurunkan skala nyeri rematik, sehingga dapat disimpulkan bahwa terdapat perbedaan yang signifikan pada kompres air hangat dan kompres jahe terhadap penurunan nyeri rematik pada lansia.

Hal ini diperkuat dengan penelitian Putri (2017), metode penelitian quasi eksperimental dengan dua kelompok pretest-postest yang terbagi kelompok intervensi (pemberian kompres jahe) dan kelompok kontrol (pemberian kompres air hangat). Teknik sampling menggunakan probability sampling dan jumlah sampel sebanyak 3 orang. Hasil penelitian mengatakan bahwa kompres jahe lebih efektif dalam menurunkan nyeri sendi dibandingkan dengan kompres air hangat.

\section{Kesimpulan}

Hasil penelitian menunjukkan bahwa nyeri sebelum dilakukan kompres air hangat dengan kompres jahe adalah skala 6 dan nyeri sesudah dilakukan kompres air hangat menjadi skala 4 sedangkan nyeri sesudah dilakukan kompres jahe menjadi skala 3 . Sehingga dapat disimpulkan ada perbedaan yang signifikan antara pemberian kompres air hangat dengan kompres jahe terhadap penurunan nyeri rematik pada lansia di Desa Blulukan, Colomadu, Karanganyar.

\section{Daftar Pustaka}

Basudewa, Dewa Gede. 2009. Menjaga Kesehatan Di Usia Lanjut Dan Mengenali Berbagai Penyakit Yang Mungkin Timbul. Diakses dari http://www.sasmitaconsulting.com/Artikel\%20Kesehatan\%20Lansia.html pada tanggal, 14 Februari2019.

Direktorat Statistik Kesejahteraan Rakyat, 2015, Profil Statistik Kesehatan 2015.Jakarta: Badan Pusat Statistik.

Kementerian Kesehatan RI. 2015. Buletin Jendela Data dan Informasi Kesehatan. Jakarta: Kemenkes.

Lestari, Indah. 2014. Terapi Kompres Jahe dan Massage Pada Osteoarthritis Sip Anti Wreda St. Theresia Dharma Bhakti Kasih Surakarta. Skripsi. Universitas Sebelas Maret Surakarta.

Martono, Hadi. 2009. Buku Ajar Boedhi-Darmojo Geriatri Ilmu Kesehatan Usia Lanjut. Jakarta: Balai Penerbit Fakultas Kedokteran Universitas Indonesia.

Nugroho, T. 2010. Buku Ajar Obstetri. Yogyakarta: Nuha Medika. 
Potter, P. A., \& Perry, A. G. 2005. Fundamental Keperawatan Edisi 7 Buku 3. Jakarta: Salemba Medika.

Putri, S. Q. D., Rahmayanti, D., Diani, N. 2017. Pengaruh Pemberian Kompres Jahe Terhadap Intensitas Nyeri Gout Artritis Pada Lansia Di Pstw Budi Sejahtera Kalimantan Selatan.Jurnal Keperawatan, 5(2), 90-95.

Rusnoto, dkk. 2015. Pemberian Kompres Hangat Menggunakan Jahe Untuk Meringankan Skala Nyeri Pada Pasien Asam Urat Di Desa Kendungwungu Kecamatan Tegowanu Kabupaten Grobogan. Jurnal Ilmiah Keperawatan Kesehatan Vol. 6 No. 1 Januri 2015: 29-39.

Wulan, R. A. 2015. Pengaruh Terapi Kompres Air Hangat Terhadap Penurunan Skala Nyeri Sendi pada Wanita Lanjut Usia di Panti Tresna Werdha Mulia Dharma Kabupaten Kubu Raya. Naskah Publikasi:Fakultas Kedokteran Universitas Tanjungpura, Pontianak.

Yohana. 2017. Perbedaan Intensitas Nyeri Osteoarthtritis Pada Lansia Sebeleum dan Sesudah Dilakukan Kompres Hangat Di Kelurahan Tlogomas Malang. Nursing News. Vol 2. No. 1 . 